
університету

ORCID 0000-0001-5069-5857

innayakovets@ukr.net

\title{
КОНЦЕПТ «МИСТЕЦЬКИЙ ПАТЕРН ХУДОЖНЬОГО МУЗЕЮ»
}

\begin{abstract}
Мета роботи. Провести ґрунтовний аналіз концепту «мистецький патерн художнього музею» та запропонувати власну трактовку даного визначення. Довести, що внаслідок сприйняття сучасного музею вже не тільки як зберігача минулого, але і як творця майбутнього, як центру актуальної інформації та активної комунікації, виникає потреба в нових формах організації музейної діяльності і всього музейного та навколомузейного простору, і особливе значення при цьому набуває образ, архітектура музейної будівлі - музейна будівля має бути твором мистецтва. Методологія дослідження проявляється у міждисциплінарності та ґрунтується на системі загальнонаукових та спеціальних методах, що, в свою чергу, відображають системний метод, культурологічний та мистецтвознавчий підходи до вивчення музейної форми, інформаційний та фрактальний підхід, термінологічний аналіз. Наукова новизна полягає у тому, що вперше запропоновано та сформульовано визначення концепту «мистецький патерн художнього музею». Доведено, що сучасний художній музей не тільки репрезентує сучасне і традиційне мистецтво, а і сама споруда музею являє собою твір мистецтва, дизайну; спостерігається значне розширення музейного та культурного простору. Висновки. Художній музей позиціоновано як мистецький амбівалентний патерн. Доведено, що архітектура виконує не тільки функцію інструменту загальнокультурної комунікації, а і внутрішньої комунікації музею, оскільки архітектурно-дизайнерське вирішення його екстер'єру та навколомузейний простір задають параметри сприйняття, алгоритми поведінки в усьому музейному просторі, занурюють відвідувача у світ художньої культури.

Ключові слова: культура, мистецтво, архітектура, дизайн, художній музей, мистецький патерн худож-
\end{abstract} нього музею, фрактал, патерн, музейний простір.

Яковец Инна Александровна, доктор искусствоведения, доцент, профрессор кафредры дизайна Черкасский государственный технологический университет

\section{Концепт «патерн искусства художественного музея»}

Цель работы. Провести основательный анализ концепта «паттерн искусства художественного музея» и предложить собственную трактовку данного определения. Доказать, что в результате восприятия современного музея уже не только как хранителя прошлого, но и как создателя будущего, как центра актуальной информации и активной коммуникации, возникает потребность в новых формах организации музейной деятельности и всего музейного и околомузейного пространства, и особое значение при этом приобретает образ, архитектура музейного здания - музейная здание должно быть произведением искусства. Методология исследования проявляется в междисциплинарности и основывается на системе общенаучных и специальных методах, что, в свою очередь, отражают системный метод, культурологический и искусствоведческий подходы изучения музейной фрормы, информационный и фрактальный подход, терминологический анализ. Научная новизна заключается в том, что впервые предложено и сформулировано определение концепта «паттерн искусства художественного музея». Показано, что современный художественный музей не только представляет современное и традиционное искусство, а и само здание музея представляет собой произведение искусства, дизайна; наблюдается значительное расширение музейного и культурного пространства. Выводы. Художественный музей позиционирован как художественный амбивалентный паттерн. Доказано, что архитектура выполняет не только функцию инструмента общекультурной коммуникации, а и внутренней коммуникации музея, поскольку архитектурно-дизайнерское решение его экстерьера и околомузейное пространство задают параметры восприятия, алгоритмы поведения во всем музейном пространстве, погружают посетителя в мир художественной культуры.

Ключевые слова: культура, искусство, архитектура, дизайн, художественный музей, паттерн искусства художественного музея, фрактал, паттерн, музейное пространство.

Yakovets Inna, Doctor of Sciences, Associate Professor, Professor of the Department of Design, Cherkasy State Technological University

The concept "artistic pattern of an art museum"

Purpose of the article. To undertake a thorough analysis of the concept of the "artistic pattern of an art museum" and propose your interpretation of this definition. To prove that due to the perception of the modern museum, not only as of the custodian of the past but also as the creator of the future, as a center of up-to-date information and active communication, there is a need for new forms of organization of museum activity and the entire museum and nearmuseum space. In this way, the image, museum building architecture becomes especially essential - a museum building should be a work of art. The methodology of the research manifests itself in interdisciplinary. It is based on a system of general scientific and unique methods, which, in their turn, reflect the systematic method, cultural and art study approaches to the study of museum form, information and fractal approach, terminological analysis. The scientific novelty is that the definition of the concept of the "artistic pattern of an art museum" has been proposed and formulated for the first time. It has been proved that the modern art museum not only represents a contemporary and traditional art but also the building of the museum itself is a work of art, design; there is a significant expansion of the museum and cultural

(с) Яковець І. О., 2019 
space. Conclusions. The art museum is positioned as an artistic ambivalent pattern. It has been proved that architecture serves not only as a tool of cultural communication but also the internal communication of the museum, since the architectural and design solution of its exterior and the near-museum space set the parameters of perception, algorithms of behavior throughout the museum space, immersing the visitor in the world of art culture.

Key words: culture, art, architecture, design, art museum, the artistic pattern of an art museum, fractal, pattern, museum space.

Актуальність дослідження. Тенденції розвитку культури і мистецтва останньої третини XX - початку XXI ст. справляють вагомий вплив на сучасний музей. Цей період в музейній практиці пов'язаний 3 кардинальними трансформаціями музейного простору і його смислів.

Значне поширення і стрімке зростання кількості музеїв мистецького профілю, i, зокрема музеїв сучасного мистецтва у світі та в Україні, набувають все більш істотного значення в житті суспільства, i це, без сумніву, підкреслює актуальність пропонованої роботи. Небувалий розквіт і популярність саме цього типу музею на тлі загального музейного буму зумовлені багатьма соціальними, художніми та культурологічними фракторами, що вимагає комплексного осмислення об'єкта нашого дослідження.

Методологія пропонованого дослідження, що має міждисциплінарний характер, ґрунтувалася на вивченні світових новітніх тенденцій розвитку музейної форми у співставленні її з музеями в Україні з позицій подальшої модернізації та вдосконалення вітчизняної музейної форми.

Системний принцип визначив стратегію наукового дослідження і допоміг розкрити цілісність і специфріку френомену сучасної музейної фрорми, а також виявити взаємозв'язки між її структурними елементами.

Інформаційний підхід дав змогу виявити нові якості об'єкта дослідження (художнього музею), важливі для розуміння його сутності та можливих напрямів розвитку на основі знання загальних властивостей та закономірностей інформаційних процесів. Інформаційно-комунікативний підхід також дав можливість з'ясувати природу власне музейної мови, її специфіку і, відповідно, особливості інформаційної системи, що використовує музей.

Використання в даній роботі термінологічного аналізу, надало можливість запропонувати авторську трактовку концепту «мистецький патерн художнього музею». Доповнює методологію фррактальний підхід, який відкриває додаткові можливості перед сучасними науками.

Аналіз досліджень і публікацій. Обґрунтування авторської позиції щодо об'єкта дослідження потребувало аналізу та переосмислення робіт широкого кола питань. Були враховані загальнофілософські, соціологічні, історичні, педагогічні, культурологічні, мистецтвознавчі підходи до аналітики музею, представлені у вітчизняній та зарубіжній літературі.

Дослідження сучасної музейної форми передбачає вивчення широкого кола питань, що стосуються як історії музейної справи і теоретичних проблем музеєзнавства, так і проблематики, пов'язаної з дослідженням музею як соціокультурного інституту і феномена культури, що актуалізується разом 3 розвитком музеєзнавства як науки у другій половині XX століття [1].

У сучасному мистецько-культурологічному знанні все більшої популярності набирає термін «патерн» (патерн розуміється як повторюваний шаблон, або зразок; елементи патерна повторюються передбачувано), що передусім пов'язано з наростаючими процесами інтеграції між різними дисциплінами, включаючи гуманітарне і негуманітарне знання. На цьому тлі відбувається змішання різних «мов» наук, і в результаті деякі терміни набувають міждисциплінарного тлумачення.

У сфері культурологічного знання першість в застосуванні терміна «патерн» належить американській дослідниці, культурологу Рут Фултон Бенедикт (1887-1948), автору книги «Patterns of Culture» («Патерни культури»), виданої в 1934 році. У теоретичній схемі вивчення культур, створеної Р. Бенедикт, був зроблений акцент на унікальності і своєрідності системних конфігурацій кожної культури окремо. Зазначені системні конфігурації культур, на думку авторки, характеризують риси сталості і спадкоємність. Слід зазначити, що в своїх роботах вона не виходить на категоріальний рівень і використовує термін «патерн» в його буквальному значенні, проте дослідниця створила основу для його наукової популяризації [2].

Пряме спостереження може виявляти візуальні патерни, як вони формуються, наприклад, в культурі і мистецтві. Вони в більшості випадків не копіюють один одного і часто є фрактальними. У мистецтві, архітектурі, дизайні різні візуальні елементи можуть комбінуватися і повторюватися, утворюючи мистецькі патерни. Таким чином, вищесказане вказує на те, що патерни є культурним френоменом, що охоплює всі сфери діяльності і життєдіяльності людини, зокрема науку, мистецтво, природу.

Мета дослідження полягає в ґрунтовному аналізі концепту «мистецький патерн художнього музею» при зосереджені уваги на тому положенні, що художній музей у нашій роботі позиціоновано як амбівалентний мистецький патерн культури, тобто не тільки як заклад, що традиційно лише зберігає, накопичує та репрезентує твори мистецтва, а і як будівля музею, що є твором мистецтва, архітектури, дизайну та викладенні власної трактовки даного визначення. В дослідженні необхідно довести, що внаслідок сприйняття сучасного музею вже не тільки як зберігача минулого, але і як творця майбутнього, як центру актуальної інформації та активної комунікації, виникає потреба в нових формах орга- 
нізації музейної діяльності і всього музейного та навколомузейного простору, і особливе значення при цьому набуває образ, архітектура музейної будівлі - музейна будівля має бути твором мистецтва.

Виклад основного матеріалу дослідження. Досліджуючи феномен художнього музею, зупинимося детальніше на тому положенні, що музей у нашому дослідженні позиціоновано як амбівалентний мистецький патерн культури, тобто не тільки як заклад, що традиційно лише зберігає, накопичує та репрезентує твори мистецтва, а і як будівлю музею, що $€$ твором мистецтва, архітектури, дизайну. Художній музей трактуємо не лише як безпосередньо традиційний художній музей, а й як узагальнену назву музеїв мистецького спрямування. А найбільш яскравими прикладами прояву динамічної складової діяльності художнього музею у XXI ст. можна вважати музеї сучасного мистецтва (Contemporary art).

Враховуючи вищевикладений матеріал, можемо сформулювати таке визначення: мистецький патерн художнього музею є амбівалентним за своєю сутністю та являє собою концептуальний культурний фрактал, що є патерном художньої культури і має символічний мистецький сенс на всіх ієрархічних рівнях.

Проаналізуємо це твердження детальніше. Історія розвитку музейної архітектури показує, що вигляд музейних будівель змінювався залежно від концепцій і підходів до розуміння музейної інституції (нині - музейної форми). Зауважимо, що, якщо з кінця XIX ст., коли почалося будівництво споруд, спроектованих спеціально для потреб конкретного музею, і до другої половини XX ст., можна говорити про можливість створення певної типології музейної архітектури за стилями, критеріями, течіями у контексті загальної теорії архітектурних стилів, то, починаючи з другої половини XX ст. і до сьогодні, складно говорити про якийсь конкретний виражений архітектурний стиль, оскільки в мистецтві (архітектурі) постмодернізму все більше виникає нових течій і напрямків, пов'язаних з появою науковотехнічних досягнень або нових філософських, культурологічних, світоглядних концепцій [3].

Дослідження будівель сучасних музеїв доводить, що різноманітні фрорми і образи, які знаходять втілення в їх архітектурі, активно обговорюють не тільки засоби масової інформації, а і наукова спільнота, існують неоднозначні трактування та відгуки, що викликають суперечки, а музейний бум, який, як відомо, триває у світі вже кілька десятиліть, супроводжуючись будівництвом великої кількості нових будівель для музеїв та розширенням і реконструкцією старих.

Власне, питання стосовно того, чи має бути музейна будівля місцем для зберігання мистецьких творів, колекцій, інших музейних предметів або бути архітектурною пам'яткою, твором мистецтва, самоцінним об'єктом показу (навіть, якщо вміст його $є$ другорядним) $€$ основним, навколо якого розвивається багаторічна дискусія. У нашому дослідженні, стверджуючи, що сьогодні музей сприймають вже не тільки як зберігача минулого, зокрема пам'яток культури і мистецтва, але і як творця майбутнього, як центр актуальної інформації та активної комунікації, ми наголошуємо саме на тому, що внаслідок цих змін виникає потреба в нових формах організації музейної діяльності і всього музейного та навколомузейного простору, і особливе значення при цьому набуває образ, архітектура музейної будівлі - музейна будівля має бути твором мистецтва.

Стає очевидним, що архітектурну форму перестали сприймати лише як утилітарну оболонку для музейного зібрання, їі роль набагато ширша, але можливості архітектури в музейній діяльності вивчені і реалізовані не повно [4]. Зазначимо, що, по-перше, зміна уявлень про місію музеїв початку XXI століття впливає на рівень екстер'єру, оскільки зовнішній вигляд будівлі, здатний втілити новий образ музею, більш відкритий і привабливий для публіки, здатний до комунікації, а по-друге, нове розуміння функцій музею робить необхідними зміни на рівні внутрішньої структури музейних будівель, що виражається в появі нових типів приміщень та в їх художньому вирішенні. Тобто роль і місія самого музею в сучасній культурі певним чином визначає значення художнього образу музейної споруди та функції архітектури в системі музею.

Важливим фрактом $\epsilon$ поступове утвердження розуміння того, що проектування музейних будівель, створення його особливого художнього образу не можна вважати тільки завданням архітектури, оскільки цей процес повинен бути усвідомлений як невід'ємна складова музейної діяльності і відбуватися у тісній взаємодії з музейними фахівцями. Це твердження відповідає актуальній тенденції посилення міждисциплінарності наукових досліджень у культурології, мистецтвознавстві, музеєзнавстві, що і доводить пропонована робота, виконана на перетині цих наук.

Важливим $€$ той факт, що значну групу досліджень становить низка робіт, які висвітлюють різні сторони функціонування художніх музеїв, музеїв сучасного мистецтва, на яких і зосереджено нашу увагу. У більшості робіт специфіка представлення сучасного мистецтва (як, власне, і саме сучасне мистецтво) співвідноситься з постмодернізмом як культурною моделлю. Багато досліджень першого десятиліття XXI ст. присвячено визначенню місця музею в соціокультурному просторі, його суспільному призначенню, окремим сторонам його діяльності. Бажанням «вписати» музей у простір сучасної економічної культури продиктована поява концепцій музею в системі трансмодерна [5].

Особливе місце серед робіт, присвячених дослідженню музею та музейності належить російському культурологу О. Сапанжі. Так, подальшого розвитку набула ії концепція «пост-музею», проте, варто відзначити, що фокус у вивченні теоретичних моделей музею в ситуації постмодерну зміщується на вивчення можливостей впливу музею на життя соціуму і культури в цілому, при цьому важли- 
ва роль належить самій споруді музею як фрактору первинного культурного діалогу, комунікації [6]. 3ауважимо також, що темі музеїв сучасного мистецтва, які у переважній більшості являють собою твори сучасного мистецтва і архітектури, присвячена значна кількість дисертаційних робіт.

Оскільки будівля музею визнається музеєзнавцями повноправним структурним елементом фрактальної музейної системи (разом з експозицією, фондами, послугами, персоналом та усною комунікацією і т. д.) [7], то вона повинна за допомогою своїх специфічних інструментів сприяти виконанню основних соціокультурних функцій музею. Тому, окрім того, що архітектура створює фрізичну оболонку для зберігання і презентації колекцій і, отже, бере участь у реалізації музейної функції документування, архітектурна споруда може відігравати істотну роль у реалізації освітньо-виховної функції музею, в основі якої і лежить теорія музейної комунікації. При такому розгляді образ самої будівлі музею може трактуватися як інструмент спілкування з відвідувачами, а деякі архітектурні елементи або особливості інтер'єру в структурі музейної експозиції можуть стати значущим аспектом і навіть виконувати роль експоната, сприяючи підвищенню рівня ефективності сприйняття експозиції [8].

Таким чином, враховуючи те, що ще до потрапляння всередину музею архітектурнодизайнерське вирішення його екстер'єру та навколомузейний простір задають параметри сприйняття, алгоритми поведінки в музейному та навколомузейному просторі, занурюють відвідувача у світ культури, то можемо стверджувати, що архітектура виконує як функцію інструменту загальнокультурної комунікації, так і внутрішньої комунікації музею.

За твердженням вітчизняних та зарубіжних науковців, комунікативна культура в контексті досліджень останніх років є однією з провідних сил, що формує сучасне мистецтво, у тому числі і презентоване музеями. Так, виникнення наприкінці 1960-х рр. теорії музейної комунікації та ії подальший інтенсивний розвиток спричинило в музейному світі справжню революцію. Комунікаційний підхід за визначенням $€$ антропоцентристським, оскільки у центрі уваги він ставить людину, тому акценти у діяльності сучасних музеїв змістилися з традиційної внутрішньої роботи у бік активної взаємодії з відвідувачем. Йдучи назустріч запитам і потребам публіки, музей надає можливість отримання інформації (зокрема, культурної, мистецької, освітньої) через розваги, перетворюючи відвідування музею в одну з форм дозвілля - тобто пропонує нові форми реалізації освітньо-виховної функції музею. Отже, комунікація перетворилася в одне з головних призначень роботи музеїв, що є позитивним досягненням.

Однак певне порушення рівноваги між традиційними функціями музею (наприклад, між функцією документування, що виражається в галузі архітектурно-дизайнерського проектування у вдосконаленні планування будівель, поліпшенні умов розміщення та зберігання творів мистецтва та колекцій, технічного оснащення не тільки приміщень для постійних експозицій і тимчасових виставок, а і фондосховищ при оптимальному взаємозв'язку всіх цих підрозділів, яка поступово відходить на другий план, поступаючись місцем освітньо-виховній функції, що знаходяться у постійному розвитку і видозмінюється залежно від конкретної культурної, економічної або політичної ситуації і трактуються сьогодні максимально широко) призводить часом до деяких протиріч у музейному житті (наприклад, поява музеїв без постійних колекцій і фондів), і архітектура є наочним тому підтвердженням. Показовим прикладом зміщення функцій музею являє собою знаменита будівля музею Гуггенхайма в Більбао архітектора Френка Гері (1997р.), деконструктивістська за архітектурним принципом, яка не містить під своєю нестандартною приголомшливою оболонкою ніякого певного музейного зібрання. Вона була побудована тільки для розміщення тимчасових виставок.

Ще одним прикладом можна вважати відкриття восени 2009 р. Національного музею мистецтв XXI cт. (MAXXI Museum) в Римі, Італія, спроектованого Захою Хадід, коли за кілька місяців до офіційного відкриття (у травні 2010 р.) за відсутності колекцій будівля була доступна для огляду, тобто оболонка для експонатів сама стала експонатом. Так само було і з Єврейським музеєм у Берліні, який протягом трьох років до фрормування постійної експозиції функціонував тільки як архітектурний об'єкт, і кількість відвідувачів за цей час перевищила двісті тисяч.

Як показує практика, нині дослідженням проблем проектування музейного простору займаються фахівці багатьох провідних архітектурних шкіл світу. У зв'язку з появою якісно нових підходів отримання і передачі інформації, способів трансляції візуальної інформації, виникненням нових видів мистецтва виникає питання, яким чином музей, а особливо художній, трансформується і пристосовується до нового часу - часу інформаційних технологій, часу, в якому змінюються парадигми, розробляються інвайроментальні підходи, як в культурі взагалі, мистецтві і архітектурі, так і в інших сферах життя.

На думку О. Бакушкіної, архітектори, проектуючи сучасні музейні будівлі, створюють концептуальні моделі архітектурного простору, за допомогою реалізації певних архітектурних сценаріїв візуальних практик, які можуть посилювати чуттєве переживання музейного простору при перебуванні в ньому, тим самим сприяючи фрормуванню в людини цілісної сенсорної картини — індивідуального досвіду відвідування [9].

Аналізуючи праці вчених, які займаються дослідженнями в галузі психології, фрізіології руху, сприйняття архітектурних форм і виникнення візуальних образів, таких як Р. Арнхейм «Мистецтво і візуальне сприйняття», Л. Веккер «Психіка і реальність. Єдина теорія психічних процесів», В. Вундт «Введення в психологію», згадана дослідниця виділяє три чуттєво-емоційні типи взаємозв'язку люди- 
ни з навколишнім світом і, зокрема, сприйняття архітектурного простору (дотиковий тип; тип, пов'язаний з чутливістю до підпорогових сигналів; структурний тип), відповідно до яких можна розподілити сценарії візуальних практик, які використовують архітектори під час проектування сучасних музейних будівель, у такі групи: 1) сценарій, пов'язаний з формуванням тактильних відчуттів (детальна робота з матеріалами, фактурами); 2) сценарій, пов'язаний із чутливістю до світла (світло стає змістом архітектурного об'єкта, наповнюючи архітектурний простір особливим змістом і переживаннями); 3) сценарій, пов'язаний з побудовою простору індивідуального сенсорного поля (створення можливості вибудувати власну просторову структуру свого сенсорного поля).

На основі аналізу архітектури музейних будівель (Музей Шаулаггер, Базель, Швейцарія; Музей Кімбелл, Форт-Уорт, Техас, США; Музей Злиття, Ліон, Франція) авторка доводить, що просторова структура музейних споруд змінюється разом зі зміною моделі взаємозв'язку «людина - світ». Сучасні візуальні практики особливо емоціогенні. Ще на початку $\mathrm{XX}$ ст. було встановлено, що емоційне явище завжди $є$ двокомпонентним [10]. Емоція, як відомо, являє собою й ставлення суб'єкта до об'єкта (перший компонент), і, що важливо, це ставлення людини до зовнішнього світу невіддільне від відображення свого переживання, стану (другий компонент). Ось на цьому другому компоненті і роблять акцент сучасні архітектори, фрормуючи їх художній образ і програмуючи сприйняття музейних споруд.

Необхідно зазначити той фракт, що архітектуру сучасних музеїв іноді критикують за те, що з інструменту комунікації вона непомітно перетворилася в один з комерційних інструментів музейного маркетингу, а також обговорюються питання, як довго триватиме інтерес публіки до архітектури видовищних музеїв-атракціонів і як майбутні покоління оцінять будівлі, подібні до музею Гуггенхайма в Більбао.

Висновки і перспективи. Таким чином, зв'язок між формою і функцією сучасної музейної архітектури виявляється більш наочним, ніж це було у попередні століття. Єдиний тип музейної будівлі, що відображає статус музею як культурної інституції, відходить у минуле. Натомість з'являються просторові і композиційні рішення, що забезпечують найкращу реалізацію тієї функції, яка була закладена в основу проекту.

Повертаючись до образу самої будівлі музею, зазначимо, що для здійснення комунікації з відвідувачами в художньому музеї надзвичайно важлива не стільки функціональна сторона архітектури, як її естетичні характеристики, оскільки музей сприймають як цілісний візуальний комплекс: художній образ його будівлі відіграє важливу роль у процесі взаємодії відвідувача і музейного та навколомузейного простору. Образ будівлі музею як раз і створює цей неповторний простір, відмежовує його від простору повсякденності і сприяє проникненню відвідувача в особливий світ музею.

Сьогодні створення музеїв сучасного мистецтва в нашій країні на новому історичному етапі вимагає як серйозних економічних витрат, так і теоретичного осмислення на основі аналізу історії та практики західноєвропейського і вітчизняного музейного досвіду.

\section{תimepamypa}

1. Яковець І. О. Художній музей XXI століття: Монографія. Черкаси: Вид. Вовчок О., 2016. 464 с.

2. Леонов И. В. Паттерны культурно-исторического процесса: парадигмально-тематический анализ: автореф. дис....д-ра культурологии: 24.00.01. СПб., 2015, 41 с.

3. Блинова Е. К., Бакушкина Е. С. Архитектура зарубежных музейных зданий второй половины XX века. Опыт типологического исследования // Архитектон: известия вузов: электр. версия журн. 2014. № 48. URL: http://archvuz.ru/2014_4/6 (дата обращения: 25.01.2015).

4. Чугунова А. В. Социокультурный образ современного музея: модели архитектурного воплощения: автореф. дис. ... канд. культурологии: 24.00.03. Санкт-Петербург, 2012. 20 с.

5. Ахмас К. Музей в эпоху трансмодерна // Музеология - музееведение в XXI веке. Проблемы изучения и преподавания: Материалы Международной научной конференции Санкт-Петербург, 14-16 мая 2008 года. Санкт-Петербург, 2009. С. 129-136.

6. Сапанжа О. С. Культурологическая теория музейности: дис. ... д-ра культурологи: 24.00.01. СанктПетербург, 2011. 378 с.

7. Сапанжа О. С. Основы музейной коммуникации: учебное пособие. Санкт-Петербург, 2007. С. 31.

8. Свецимский Е. Модернизация музейных экспозиций: методические рекомендации / сост. и пер. М. Б. Гнедовский. Москва, 1989. С. 11-12.

9. Бакушкина Е. С. Архитектура современных музейных зданий. Формирование смысловых моделей // Вестник КемГУКИ. 2016. № 34. С. 102-108.

10. Вундт В. М. Введение в психологию. Москва: КомКнига, 2007. 168 с.

\section{References} Ukrainian]

1. Yakovets, I. O. (2016). Art museum of the 21st century: A monograph. Cherkasy: O. Vovchok publisher. [in

2. Leonov, I. V. (2015). Patterns of cultural-historical process: A paradigm-themed analysis: Extended abstract of Doctoral thesis in Cultural Studies. Saint Petersburg. [in Russian].

3. Blinova, E. K., Bakushkina, E. S. (2014). Architecture of the foreign museum buildings of the second half of the $20^{\text {th }}$ century: An attempt of typological research. Architecton: Proceedings of higher education. 48. Retrieved January 25, 2015 from: http://archvuz.ru/2014_4/6 [in Russian]. 